\title{
Health Communication Campaign of Clean and Healthy Living Behaviour (PHBS) in Covid-19 Pandemic Era
}

\author{
WAYAN TANTRE WIYANE \\ SURAYA MANSUR \\ Universitas Mercu Buana, Indonesia
}

\begin{abstract}
This article explains the results of a research about the health communication campaign on Clean And Healthy Living Behaviour (PHBS) or clean and healthy lifestyle behaviour in the era of the Covid-19 pandemic. Utilising a positivistic paradigm, the method employed in this research is a survey explanatory method and quantitative approach. Samples were selected through a purposive sampling technique, among people in Pura Aditya Jaya Rawamangun Jakarta which yielded 119 respondents, with a sampling error of $5 \%$. The technique of data analysis used in this research is simple regression analysis. The result of the research shows that there is a positive influence of counselling and belowthe-line media on clean and healthy lifestyle behaviour among people in Aditya Jaya Rawamangun Jakarta temple. However, the variable of Campaign through Counselling is more dominant in influencing the clean and healthy lifestyle behaviour of people in Pura Aditya Jaya Rawamangun Jakarta, compared to the variable of Campaign through below-the-line media. In conclusion, this research proves that the social learning theory is effective in the campaign which results in behavioural changes in society.
\end{abstract}

Keywords: Social learning theory, campaign, clean and healthy lifestyle behaviour (PHBS), counseling, below-the-line.

\section{INTRODUCTION}

Health communication is a part of human communication with the main focus on how individuals deal with health issues and how important it is to maintain their health. During the pandemic of COVID-19, health communication in the form of media campaigns are used to educate the public on health issues. There are several things that are discussed in the campaign inculding, media and the behaviour to live healthily (Mohamad \& Azlan, 2020; Sampurno, Kusumandyoko \& Islam, 2020; Citrasiwi, Hafiar \& Sjoraida, 2017).

Behaviour is the main factor affecting the moral degree of society. There are so many health issues in Indonesia that are caused by people being unable to implement the clean and healthy living behaviour (PHBS). The PHBSS covers five orders which are: order in the household, order in the school, order in health institutions, order in the workplace, and order in public spaces.

PHBS is an Indonesian government program issued by the Ministry of Health in the Ministerial Decree No. 1193/MENKES/SK/X/2004 (Kemenkes RI, 2020). PHBS is important to be introduced, widespread and established in places where many people gather, because it concerns the lifestyle of society.

PHBS campaigns are a national program -- focussing on physical activity or daily sport, consuming fruits and vegetables, and washing hands with soap (Advertorial, 2020) - that is constantly being improved to ensure that Indonesia reaches the ideal state of public health. It is a social engineering initiative that aims to change as many people in the community as 
possible, to be the agent of change that can raise the quality of daily behaviour to live in clean and healthy manner (Proverawati \& Rahmawati, 2012).

As for the programs, PHBS has healthy lifestyle counselling, youth empowerment, healthy school development, and lastly the utilisation of media to help promote the awareness of a healthy lifestyle. Admittedly, there are other programs that intersect with PHBS' campaign and even support the implementation of the PHBS campaign (WHO, 2020a; WHO, 2020b).

Since the outbreak of Covid-19 in Indonesia, many prevention efforts have been enforced to break the spreading chain of the COVID-19 virus. Some effective ways which were enforced are social distancing, self-isolation, and the implementation of clean and healthy lifestyle behaviour (PHBS). Aside from the programs by the Ministry of Health, PHBS has also been promoted by the Ministry of Public Works and Public Housing in many programs and activities, to help curb the spread of Covid-19.

In particular, the Covid-19 pandemic has seen the Indonesian government's efforts to further familiarise the public with clean and healthy lifestyle and create a health-conscious community equipped with knowledge and awareness, similar to the PHBS movement. The increased effort was made as Indonesia continues to battle with Covid-19. At the time this article was written (01/02/20), there were 1.667 confirmed cases from 32 provinces (Kesehatan, 2020).

\section{Pura}

Pura, or Hindu temple, is an effective and efficient place to spread health information because it is the Hindu place of worship where the Hindus, including the trustworthy and respected figures, gather to do their religious practices. PHBS campaign activities have been carried out continuously each year and in 27 temples in the Jabodetabek area (Karo, 2020).

Pura is not only a place of worship but also the center of other activities for Hindus such as education, art and culture, social community, as well as the center of information. Therefore, Pura is a suitable place to conduct the PHBS campaign as an effort to maintain public health. Some of the practices highlighted in relations to clean and healthy lifestyle behaviour in Pura are wearing a clean, neat, and polite outfit, washing hands with soap in clean running water before starting prayers or other activities, using healthy latrines, managing waste properly, not smoking, and not taking drugs in temples, not spitting, eradicating mosquito larvae, and others. With the PHBS campaign introduced in Pura, it is expected that a healthy and clean environment will be created, with the support of the Hindus and visitors of Pura who implement a clean and healthy lifestyle behaviour (Yasa, 2020).

The government is responsible for planning, regulating, implementing, fostering, and supervising the implementation of health efforts that are evenly distributed to every layer of the community. However, the government can't work on it alone. Therefore, the role of other parties including those of business and private sectors is necessary. In carrying out efforts to promote the implementation of PHBS in public places including temples, the government also needs cooperation from all layers of society (Karuniawati \& Putrianti, 2020).

Parisada Hindu Dharma Indonesia (PHDI), is an example of a Hindu organisation that is carrying out these efforts. PHDI expects everyone to practice a clean lifestyle and comply with calls and regulations from the government to tackle COVID-19. As stated by the head of Health and Social Humanity Parisada Hindu Dharma Indonesia (PHDI), Nyoman Suartanu, in the office of National Disaster Management (BNPB), Jakarta, on Saturday (28/3), "Practice clean and 
healthy lifestyle activities through the healthy living movement" (Sukarma, 2016; Paramajaya, 2018).

The values adhered to in Hinduism is the Tri Hita Kirana (THK). It is one of Balinese local wisdom, the heritage of Hinduistic ancestors. THK has been the way of life of the Balinese since long ago. The term Tri Hita Kirana comes from the Sanskrit language, Tri means three, Hita means happiness/welfare, and Karana means the cause. So Tri Hita Kirana means 3 things/elements that cause happiness and welfare consists of the element Prahyangan, which is a harmonious relationship of man and God, the element Pawongan, which is a harmonious relationship of fellow men, and the element Palemahan, which is a harmonious relationship of the human and natural world. Environmental management is a very important aspect of THK, especially in the element Palemahan. Environmental management which is carried out with the principle of responsibility, the principle of sustainability, and the principle of benefit aim to realise the development of a community that believes in and is obedient to Ida Sang Hyang Widhi Wasa (Paramajaya, 2018).

The PHBS campaign carried out by the Ministry of Health is one of the stimuli given to the public, to causing the response desired by the Ministry of Health. This is supported by the Stimulus-Response theory which assumes that a stimulus given to the audience will have a response effect within the audience (Mulyana, 2007).

There were researches about stimulus responses that have been conducted such as the response of elementary students to an animated video of alertness (Iskandar, Mansur, \& Ritonga, 2020), the Effect of Online Game (Saputra, 2016), response to the advertisement (Hardianto, 2019); Jamaah response to Da'wah (Sakinah, Sumijati, \& Rahman, 2020; Fajriani, Aliyudin, \& Ridwan, 2020; Munawaroh, Suherdiana, \& Nase, 2020) and response to the Covid19 pandemic policy on education (Robandi, 2020).

The phenomenon regarding the PHBS campaign in tackling the pandemic Covid-19 can be studied with health communication theory, which is the communication between people with the primary focus on how individuals deal with health issues and how they maintain their health (Grier \& Bryant, 2005; Namkoong, Nah, Record \& Van Stee, 2017). Health communication uses communication skills and knowledge to positively influence the health behaviour of individuals, families, and communities. It covers information about disease prevention, health promotion, health maintenance policy, and raises individual awareness on health issues, health risks, and health solutions. Advocacy media, mass media, entertainment media, and the Internet are various forms of health communication, intending to raise awareness and maintain the degree of health (Thomas, 2006; Nicely Aken, 2008). It is very important to educate people during the Covid-19 pandemic, with Health Communication (Rimal \& Lapinski, 2009; Snyder, 2007; Peng, Pei, Zheng, Wang, \& Zhang, 2020).

The current COVID-19 pandemic situation amplified the pivotal need for health education and health promotion. Some issues included in the discussion about health are GERMAS or society's healthy living movement during pandemic, clean and healthy lifestyle, ways to maintain health, and ways to deal with diseases. Health communication is a branch of persuasive communication, as its objective is to influence and persuade audiences to change their attitude and behaviour to start living healthy (Grier \& Bryant, 2005).

This research, therefore, aims to examine the implementation of campaigns in Pura/temples carried out by PHDI and the Indonesian Ministry of Health since 2014. Conducting health promotions at a Pura during COVID-19 is a relatively new method in the PHBS campaign, and therefore creates an urgent need for research to be carried out. 
This is also supported by the fact that the recent drop in environmental quality compared to previous years when the Pura received the PHBS award. Researchers assume that this phenomenon occurs due to a lack of communication in the implementation process of the campaign. Therefore, this research will describe the Perilaku Hidup Bersih dan Sehat (PHBS) campaign through consultations sessions and media below-the-line in Pura Aditya Jaya Rawamangun.

\section{Social Learning Theory}

\section{LITERATURE REVIEW}

Social learning theory implies that the stimulus-response theory is a simple learning principle, where the effect is a learning principle that is a reaction to a certain stimulus. Thus, one can explain a close relationship between media messages and audience reactions. The main elements of this theory are: (a) a message (stimulus), (b) a receiver (organism), and (c) an effect (response) (McQuail, 2016).

The principle of Stimulus-response is the basic theory of hypodermic needle, a classic theory about the process of strong mass media effect. As explained earlier, the hypodermic theory sees media coverage as drugs injected into the audience's blood vessels and results in expected reaction (McQuail, 2016; Bungin, 2009).

\section{Health Communication}

Health communication includes communication strategies to convey and influence through the knowledge, attitudes and practices of individuals and communities regarding health care. This is expressed through health promotions which seek to improve the social climate by encouraging healthy behaviour, creating awareness, changing attitudes, and motivating individuals to adopt recommended behaviours (Ishikawa \& Kiuchi, 2010; Snyder, 2007).

Nowadays, health promotion campaigners make use of the rapidly developing digital technology as a communication tool, which makes it easier to target audiences, adjust messages and engage people in interactive and sustainable exchanges about health (Manimaran \& Samsudin, 2015) . For example, many of us have come across and encountered billboards, pamphlets, ads that contain the words asking to use a mask, always wash hands with soap in running water, keep your distance and so on (Grier \& Bryant, 2005; Rimal \& Lapinski, 2009); and we need health literacy (Emma et al., 2015).

The application of effective communication methods and techniques can help convey health messages to the public effectively and is able to change their perceptions and behaviour towards personal health, their families and their environment. In the current situation, the effort to break the chain of Covid-19 transmission will be difficult to be arried out if it is not accompanied by public health education (Wahyudin \& Uud, 2016; Ayub, Hasim, Yahya, Hamzah, \& Bakar, 2019). Health educators are challenged in carrying out education to their families and communities. This is related to health literacy within the community (Karim, 2020; Emma et al., 2015).

\section{a. Campaign}

Public communication campaign is defined as an effort that is aimed to inform and influence the behaviour of a certain group of people in a specific period using a series of organised communication activities that includes message composing through various channels to gain the non-commercial benefit of a person and a society (Rice \& Atkin, 2017). 
Communication in a campaign involved discussion and idea-sharing between campaigners and the targeted public to persuade a large number of targeted audiences to act on the issue considered urgent to be addressed immediately. Campaign communication is started with a dialogue, emphasising the long term interaction (Klingemann, Rommele, Voltmer \& Rommele, 2002b; Klingemann \& Römmele, 2002a).

\section{b. Counselling}

Counseling is a professional activity involving the relationship between a counselor with an individual or a group of individuals. Like an interpersonal relationship in general, in the process of counseling occurs the process of interaction and communication between individuals with other individuals (counselors-counselee). Mastery of communication skills is a basic prerequisite for counselors to be able to use various counseling skills effectively and efficiently. It should be understood that almost all of the counseling skills involve the counselor's communication skills. A good understanding of communication skills should be based on an in-depth study and understanding of communication philosophy (Hariko, 2017).

Some of the previous researches about counselling are about Clean and Healthy Habits (Andriansyah \& Rahmantari, 2013; Zukmadani, Karyadi \& Kasrina, 2020; Malik, Bafadal, Wahyuni \& Sahidin, 2020; Handayani, Novaryatiin \& Ardhany, 2016), performance and paradigms of counselling (Ismayani, 2019; Karsidi, 2001), and the significance of extension agent toward human behaviour (Amanah, 2007).

The counselling mentioned in this research means the activity of raising awareness toward people who live nearby or just visited Pura Aditya Jaya Rawamangun to maintain cleanliness, or specifically the clean and healthy lifestyle behaviour (PHBS), especially in the COVID-19 pandemic era. The counselling was carried out by conveying directly to the community by PHBS campaign officers.

\section{c. Below-the-line Media}

The campaign is also carried out via below-the-line media. Below-the-line media is defined as any short-term sale marketing or promotion activities that are aimed to embrace customers to be aware of a product. TTypes of below-the-line advertising includes the usage of eaflets, posters, banners, billboards, bus panels, bus stops, point of purchase (POP), stickers, shop signs, flyers, hanging displays, and so on (Rank, 2010).

The communication carried out by PHDI and the Ministry of Health also uses indirect communication to inform and communicate to people by distributing leaflets, pocket notes, t-shirts, yoga mattresses, that contains information regarding PHBS. The Public Health Office uses media in the form of banners, billboards, posters, and stickers about PHBS information which is distributed to the people living in the Pura or temple area, and people who are visiting Pura Aditya Jaya Rawamangun.

\section{METHODOLOGY}

This research is quantitative in nature. The primary data is obtained by a questionnaire distributed among 119 people who frequent the Aditya Jaya Rawamangun Temple. The sample was chosen from the particular Temple because of its significant past. Previously, the temple was awarded by PHDI, SDHD, and the Ministry of Health of Indonesia in 2017 for implementing PHBS. However, the implementation is no longer maintained lately. 
The sample was calculated utilizing the Slovin Formula with a 5\% sampling error. In this research, the writer uses the incidental sampling technique, and the sample is determined based on coincidence. Anyone who accidentally or incidentally meets the researcher can be used as a sample if the person seems to be a suitable data source (Sugiyono, 2012).

This matter is firstly brought up because of a phenomenon that occurs in e.

The data analysis technique used in this research is inferential statistical analysis, which is a statistical technique used to analyse sample data, and the result is applied to the population (Sugiyono, 2012). The hypothesis formulation of this research is as follow:

Ho: There are no significant effects of PHBS counselling campaign and media (below-the-line) on clean and healthy lifestyle behaviour in Pura Aditya Jaya Rawamangun.

H1: There are effects of PHBS counselling campaigns and media (below-the-line) on clean and healthy lifestyle behavior in Pura Aditya Jaya Rawamangun.

\section{Background of respondents}

\section{RESULTS AND DISCUSSION}

More than half of the respondents are female (54.6\%) and the rest, male (45.4\%). The educational background of most respondents is bachelor graduate $(42.9 \%)$, students $(21 \%)$ or master graduates (16\%). Most respondents earn 0-1.9 million rupiah (29.4\%), 2-3 million rupiah (23.5\%), and 4-5.9 million rupiah (19.3\%).

Table 1: Infected Possibility

\begin{tabular}{llcccc}
\hline & & & & \multicolumn{2}{c}{ Cumulative } \\
& & Frequency & Percent & Valid Percent & Percent \\
\hline Valid & Highly Possible & 18 & 15.1 & 15.1 & 15.1 \\
& Possible & 54 & 45.4 & 45.4 & 60.5 \\
& Quite Possible & 38 & 31.9 & 31.9 & 92.4 \\
& Highly Impossible & 9 & 7.6 & 7.6 & 100.0 \\
& Total & 119 & 100.0 & 100.0 & \\
\hline
\end{tabular}

Half of the respondents had the awareness that they could possibly be infected by COVID-19 (45.4\%) and highly possibly infected (15.1\%). This awareness is expected to increase the awareness to practice a healthy and clean lifestyle.

Table 2: Face-Touching

\begin{tabular}{llcccc}
\hline & & & & Cumulative \\
& & Frequency & Percent & Valid Percent & Percent \\
\hline Valid & 1x per hour & 49 & 41.2 & 41.2 & 41.2 \\
& 2x per hour & 17 & 14.3 & 14.3 & 55.5 \\
& 3x per hour & 22 & 18.5 & 18.5 & 73.9 \\
& 4x per hour & 11 & 9.2 & 9.2 & 83.2 \\
& above 5 x per hour & 20 & 16.8 & 16.8 & 100.0 \\
& Total & 119 & 100.0 & 100.0 & \\
\hline
\end{tabular}

Half of the respondents stated that they touched their face once per hour in a day (41.2\%), 3x per hour (18.5\%), above 5 times per hour (16.8\%), 2 times per hour (14.3\%). 
Table 3: Hair-Touching

\begin{tabular}{llcccc}
\hline & Frequency & Percent & Valid Percent & $\begin{array}{c}\text { Cumulative } \\
\text { Percent }\end{array}$ \\
\hline Valid & 1x per hour & 53 & 44.5 & 44.5 & 44.5 \\
& 2x per hour & 13 & 10.9 & 10.9 & 55.5 \\
& 3x per hour & 20 & 16.8 & 16.8 & 72.3 \\
& 4x per hour & 9 & 7.6 & 7.6 & 79.8 \\
& above 5 x per & 24 & 20.2 & 20.2 & 100.0 \\
& hour & & & & \\
& Total & 119 & 100.0 & 100.0 & \\
\hline
\end{tabular}

Almost half of the respondents touched their hair once per hour (44.5\%), above 5 times per hour (20.2\%), 3 times per hour (16.8\%), and 2 times per hour (10.9\%).

Tabel 4: Ear-Touching

\begin{tabular}{llcccc}
\hline & Frequency & Percent & $\begin{array}{c}\text { Valid } \\
\text { Percent }\end{array}$ & $\begin{array}{c}\text { Cumulative } \\
\text { Percent }\end{array}$ \\
\hline Valid & 1x per hour & 69 & 58.0 & 58.0 & 58.0 \\
& 2x per hour & 14 & 11.8 & 11.8 & 69.7 \\
& 3x per hour & 7 & 5.9 & 5.9 & 75.6 \\
& 4x per hour & 5 & 4.2 & 4.2 & 79.8 \\
above 5 x per hour & 24 & 20.2 & 20.2 & 100.0 \\
& Total & 119 & 100.0 & 100.0 & \\
\hline
\end{tabular}

More than half of the respondents touched their ears once per hour $(58 \%)$, above 5 times per hour (20.2\%), 2 times per hour (11.8\%).

Table 5: Eye-Touching

\begin{tabular}{llcccc}
\hline & & & & Cumulative \\
& & Frequency & Percent & Valid Percent & Percent \\
\hline Valid & 1x Per Hour & 59 & 49.6 & 49.6 & 49.6 \\
& 2x Per Hour & 23 & 19.3 & 19.3 & 68.9 \\
& 3x Per Hour & 11 & 9.2 & 9.2 & 78.2 \\
& 4x Per Hour & 5 & 4.2 & 4.2 & 82.4 \\
& Above 5 X Per Hour & 21 & 17.6 & 17.6 & 100.0 \\
& Total & 119 & 100.0 & 100.0 & \\
\hline
\end{tabular}

Almost half of the respondents touched their eyes once per hour (49.6\%), 2 times per hour (19.3\%), above 5 times per hour (17.6\%).

Tabel 6: Nose-Touching

\begin{tabular}{llcccc}
\hline & & & & \\
& & Frequency & Percent & Valid Percent & $\begin{array}{c}\text { Cumulative } \\
\text { Percent }\end{array}$ \\
\hline Valid & 1x per hour & 59 & 49.6 & 49.6 & 49.6 \\
& 2x per hour & 15 & 12.6 & 12.6 & 62.2 \\
& 3x per hour & 18 & 15.1 & 15.1 & 77.3 \\
& 4x per hour & 10 & 8.4 & 8.4 & 85.7 \\
& above 5 x per hour & 17 & 14.3 & 14.3 & 100.0 \\
& Total & 119 & 100.0 & 100.0 & \\
\hline
\end{tabular}


Nearly half of the respondents stated that they touched their nose once per hour (49.6\%), 3 times per hour (15.1\%), above 5 times per hour (14.3\%), and 2 times per hour $(12.6 \%)$.

Table 7: Mouth-Touching

\begin{tabular}{llcccc}
\hline & & & & Cumulative \\
& & Frequency & Percent & Valid Percent & Percent \\
\hline Valid & 1x per hour & 54 & 45.4 & 45.4 & 45.4 \\
& 2x per hour & 17 & 14.3 & 14.3 & 59.7 \\
& 3x per hour & 18 & 15.1 & 15.1 & 74.8 \\
& 4x per hour & 9 & 7.6 & 7.6 & 82.4 \\
& above 5 x per hour & 21 & 17.6 & 17.6 & 100.0 \\
& Total & 119 & 100.0 & 100.0 & \\
\hline
\end{tabular}

Almost half of the respondents touched their mouth once per hour (45.4\%), above 5 times per hour (17.6\%), 3 times per hour (15.1\%), and 2 times per hour (14.3\%).

Table 8: Cheek Touching

\begin{tabular}{llcccc}
\hline & & Frequency & Percent & Valid Percent & $\begin{array}{c}\text { Cumulative } \\
\text { Percent }\end{array}$ \\
\hline Valid & 1x Per Hour & 56 & 47.1 & 47.1 & 47.1 \\
& 2x Per Hour & 17 & 14.3 & 14.3 & 61.3 \\
& 3x Per Hour & 15 & 12.6 & 12.6 & 73.9 \\
& 4x Per Hour & 8 & 6.7 & 6.7 & 80.7 \\
& Above 5 X Per Hour & 23 & 19.3 & 19.3 & 100.0 \\
& Total & 119 & 100.0 & 100.0 & \\
\hline
\end{tabular}

Almost half of the respondents touched their cheeks $1 \mathrm{x}$ per hour (47.1\%), above 5 times per hour (19.3\%), 2 times per hour (14.3\%), 3 times per hour (12.6\%).

Tabel 9: Chin Touching

\begin{tabular}{llcccc}
\hline & & & & \multicolumn{2}{c}{ Cumulative } \\
& & Frequency & Percent & Valid Percent & Percent \\
\hline Valid & 1x Perjam & 68 & 57.1 & 57.1 & 57.1 \\
& 2x Perjam & 13 & 10.9 & 10.9 & 68.1 \\
& 3x Perjam & 8 & 6.7 & 6.7 & 74.8 \\
& 4x Perjam & 4 & 3.4 & 3.4 & 78.2 \\
& Diatas 5 X Perjam & 26 & 21.8 & 21.8 & 100.0 \\
& Total & 119 & 100.0 & 100.0 & \\
\hline
\end{tabular}

More than half of the respondents touched their chin once per hour (57.1\%), above 5 times per hour (21.8\%), and 2 times per hour (10.9\%). The findings above indicated that the respondents are highly at risk to COVID-19 if they did not always wash their hands.

Table 10: Hand Hygiene Steps

\begin{tabular}{llcccc}
\hline & & & & \multicolumn{2}{c}{ Cumulative } \\
& & Frequency & Percent & Valid Percent & Percent \\
\hline Valid & Only Water & 2 & 1.7 & 1.7 & 1.7 \\
& Soap Without Water & 2 & 1.7 & 1.7 & 3.4 \\
& Soap And Water & 113 & 95.0 & 95.0 & 98.3 \\
& Water And Soap Without Hand & 2 & 1.7 & 1.7 & 100.0 \\
& Sanitizer & & & & \\
& Total & 119 & 100.0 & 100.0 \\
\hline
\end{tabular}


Most of the respondents regularly wash their hands with soap (95\%), which means the respondents have the awareness of getting infected by COVID-19 if they did not always wash their hands.

Table 11: Vegetables and Fruits Intake

\begin{tabular}{llcccc}
\hline & & & & Cumulative \\
& & Frequency & Percent & Valid Percent & Percent \\
\hline Valid & Never & 5 & 4.2 & 4.2 & 4.2 \\
& 1-2 portionday/ & 90 & 75.6 & 75.6 & 79.8 \\
& 3-4 portion/day & 20 & 16.8 & 16.8 & 96.6 \\
& 5 & 4 & 3.4 & 3.4 & 100.0 \\
& Total & 119 & 100.0 & 100.0 & \\
\hline
\end{tabular}

Most of the respondents consumed 1-2 portions of vegetables and fruits per day (75.6\%). The data implied that the respondents maintained their health by consuming vegetables and fruits.

Table 12: Exercise

\begin{tabular}{llcccc}
\hline & & & & Cumulative \\
& & Frequency & Percent & Valid Percent & Percent \\
\hline Valid & Never & 11 & 9.2 & 9.2 & 9.2 \\
& 5-10 Minutes Per Day & 50 & 42.0 & 42.0 & 51.3 \\
11-20 Minutes Per Day & 22 & 18.5 & 18.5 & 69.7 \\
21-30 Minutes Per Day & 19 & 16.0 & 16.0 & 85.7 \\
More Than 30 Minutes Per Day & 17 & 14.3 & 14.3 & 100.0 \\
& Total & 119 & 100.0 & 100.0 & \\
\hline
\end{tabular}

Almost half of the respondents exercised for 5-10 minutes per day (42\%), 11-20 minutes per day (18.5\%), 21-30 minutes per day (16\%). The data showed that the respondents are aware of their health by exercising although only for 5-10 minutes per day.

Table 13: Sun-Bathing

\begin{tabular}{llcccc}
\hline & & & Valid & Cumulative \\
& & Frequency & Percent & Percent & Percent \\
\hline Valid & Never & 4 & 3.4 & 3.4 & 3.4 \\
& 5-10 Minutes Per Day & 71 & 59.7 & 59.7 & 63.0 \\
& 11-20 Minutes Per Day & 27 & 22.7 & 22.7 & 85.7 \\
& 21-30 Minutes Per Day & 8 & 6.7 & 6.7 & 92.4 \\
& More Than 30 Minutes Per Day & 9 & 7.6 & 7.6 & 100.0 \\
& Total & 119 & 100.0 & 100.0 & \\
\hline
\end{tabular}

Half of the respondents sun-bath for 5-10 minutes per day (59.7\%), 11-20 minutes per day $(22.7 \%)$. The data implied that the respondents are aware of the importance of sunbathing to gain natural vitamin D, immunity, and avoid the risk of COVID-19.

Table 14: Sleep Behavior

\begin{tabular}{llcccc}
\hline & & Frequency & Percent & Valid Percent & Cumulative Percent \\
\hline Valid & 8 Hours Per Day & 47 & 39.5 & 39.5 & 39.5 \\
& More Than 8 Jam Per Day & 60 & 50.4 & 50.4 & 89.9 \\
& Less Than 8 Jam Per Day & 12 & 10.1 & 10.1 & 100.0 \\
& Total & 119 & 100.0 & 100.0 & \\
\hline
\end{tabular}


One of the healthy lifestyle criteria is maintaining sleep behaviour. Half of the respondents stated that they sleep more than 8 hours per day (50.4\%) and 8 hours per day (39.5\%) which implied that the respondents are healthy.

Table 15: Air Circulation

\begin{tabular}{llcccc}
\hline & & Frequency & Percent & Valid Percent & Cumulative Percent \\
\hline Valid & Enough & 46 & 38.7 & 38.7 & 38.7 \\
& Lack & 73 & 61.3 & 61.3 & 100.0 \\
& Total & 119 & 100.0 & 100.0 & \\
\hline
\end{tabular}

More than half of the respondents lived in houses that lack air circulation (61.3\%). The rest stated that their houses have enough air circulation (38.7\%). The data showed that the respondents are highly at risk to COVID-19.

Table 16: Defecation Habit

\begin{tabular}{llcccc}
\hline & & & Valid & Cumulative \\
& & Frequency & Percent & Percent & Percent \\
\hline Valid & In-House Toilet & 118 & 99.2 & 99.2 & 99.2 \\
& Ground Hole & 1 & .8 & .8 & 100.0 \\
& Total & 119 & 100.0 & 100.0 & \\
\hline
\end{tabular}

Most of the respondents stated that they have a toilet inside their house and a defecation habit in the toilet (99.2\%). The data implied that the respondents are aware of their health.

Table 17: Organic And Inorganic Waste Knowledge

\begin{tabular}{llcccc}
\hline & & Frequency & Percent & Valid Percent & Cumulative Percent \\
\hline Valid & In River & 118 & 99.2 & 99.2 & 99.2 \\
& On Road & 1 & .8 & .8 & 100.0 \\
& Total & 119 & 100.0 & 100.0 & \\
\hline
\end{tabular}

Most of the respondents can differentiate between organic and inorganic waste (99.2\%). The data showed that the respondents are aware of the sustainability of the environment and health in regards to organic and inorganic waste.

Table 18: Waste Sorting

\begin{tabular}{llcccc}
\hline & & Frequency & Percent & Valid Percent & Cumulative Percent \\
\hline Valid & Yes & 80 & 67.2 & 67.2 & 67.2 \\
& No & 26 & 21.8 & 21.8 & 89.1 \\
& Maybe & 13 & 10.9 & 10.9 & 100.0 \\
& Total & 119 & 100.0 & 100.0 & \\
\hline
\end{tabular}

More than half of the respondents stated that they sort organic and inorganic waste $(67.2 \%)$, do not sort the waste $(21.8 \%)$, and maybe (10.9\%). The data implied that the respondents are aware of the sustainability of the environment in regards to waste sorting. 
Table 19: Wear Mask

\begin{tabular}{llcccc}
\hline & & Frequency & Percent & Valid Percent & Cumulative Percent \\
\hline Valid & Yes & 91 & 76.5 & 76.5 & 76.5 \\
& No & 12 & 10.1 & 10.1 & 86.6 \\
& Maybe & 16 & 13.4 & 13.4 & 100.0 \\
& Total & 119 & 100.0 & 100.0 & \\
\hline
\end{tabular}

More than half of the respondents always put their masks on when they are outside (76.5\%), do not wear a mask (10.1\%), and maybe (13.4\%). The data showed that the respondents are aware of the possibility of being infected by COVID-19 if they did not wear a mask.

Table 20: Stay At Home

\begin{tabular}{cccccc}
\hline & & & & Cumulative \\
& & Frequency & Percent & Valid Percent & Percent \\
\hline Valid & Strongly Agree & 69 & 58.0 & 58.0 & 58.0 \\
& Agree & 46 & 38.7 & 38.7 & 96.6 \\
& Disagree & 4 & 3.4 & 3.4 & 100.0 \\
& Total & 119 & 100.0 & 100.0 & \\
\hline
\end{tabular}

More than half of the respondents agree with the idea of staying at home (58\%) and disagree (38.7\%). The data showed that the respondents are aware of the possibility of being infected by COVID-19 if they are outside.

Table 21: Social Distancing

\begin{tabular}{llcccc}
\hline & & & & Cumulative \\
& & Frequency & Percent & Valid Percent & Percent \\
\hline Valid & Very Serious & 69 & 58.0 & 58.0 & 58.0 \\
& Serious & 50 & 42.0 & 42.0 & 100.0 \\
& Total & 119 & 100.0 & 100.0 & \\
\hline
\end{tabular}

More than half of the respondents are very serious to practice social distancing (58\%) and serious (42\%). The data implied that the respondents are aware of the risk of being infected by COVID-19 if they did not practice social distancing.

Table 22: Campaign Through Counselling

\begin{tabular}{llcccc}
\hline & & & & Cumulative \\
& & Frequency & Percent & Valid Percent & Percent \\
\hline Valid & Interesting & 85 & 71.4 & 71.4 & 71.4 \\
& Not Interesting & 34 & 28.6 & 28.6 & 100.0 \\
& Total & 119 & 100.0 & 100.0 & \\
\hline
\end{tabular}

Most of the respondents stated that the PHBS campaign through counselling conducted by the Ministry of Health in Pura is interesting (71.4\%) and the rest stated not interesting (28.6\%). 
Table 23: Campaign Through Below the Line

\begin{tabular}{llcccc}
\hline & & & & Cumulative \\
& & Frequency & Percent & Valid Percent & Percent \\
\hline Valid & Interesting & 90 & 75.6 & 75.6 & 75.6 \\
& Not Interesting & 29 & 24.4 & 24.4 & 100.0 \\
& Total & 119 & 100.0 & 100.0 & \\
\hline
\end{tabular}

More than half of the respondents perceived the PHBS campaign through below-theline media by the Ministry of Health in Pura as interesting (75.6\%), and the rest stated not interesting (24.4\%).

Table 24: Variable Y Clean And Healthy Lifestyle

\begin{tabular}{llcccc}
\hline & & & & Cumulative \\
& & Frequency & Percent & Valid Percent & Percent \\
\hline Valid & Healthy Lifestyle & 47 & 39.5 & 39.5 & 39.5 \\
& Less Healthy Lifestyle & 58 & 48.7 & 48.7 & 88.2 \\
& Unhealthy Lifestyle & 14 & 11.8 & 11.8 & 100.0 \\
& Total & 119 & 100.0 & 100.0 & \\
\hline
\end{tabular}

Less than half of the respondents practised a less healthy lifestyle $(48.7 \%)$, a healthy lifestyle (39.5\%), and an unhealthy lifestyle (11.8\%). The data showed that the respondents should be more aware of practising a healthy lifestyle during the pandemic.

Table 25: Model Summary

\begin{tabular}{ccccc}
\hline Model & R & R Square & Adjusted R Square & $\begin{array}{c}\text { Std. Error Of The } \\
\text { Estimate }\end{array}$ \\
\hline 1 & $.904^{\text {a }}$ & .818 & .780 & .213 \\
\hline a. Predictors: (Constant), Variablex2, Variablex1 & &
\end{tabular}

Based on the table above, PHBS Campaign through counselling and below the line media are strongly correlated and significant with a healthy lifestyle of 0.904 . Not only that, PHBS Campaign through counselling and below the line media contribute $81.8 \%$ to the healthy lifestyle of the community in Pura Aditya Jaya Rawamangun, Jakarta.

Table 26: Anova ${ }^{\mathrm{a}}$

\begin{tabular}{llccccc}
\hline Model & & Sum of Squares & df & Mean Square & F & Sig. \\
\hline 1 & Regression & 19.854 & 20 & .993 & 21.954 & $.000^{\mathrm{b}}$ \\
& Residual & 4.431 & 98 & .045 & & \\
& Total & 24.286 & 118 & & & \\
\hline
\end{tabular}

a. Dependent Variable: VARIABLE Y

b. Predictors: (Constant), PHBS Campaign

Table 27: Coefficients ${ }^{\mathrm{a}}$

\begin{tabular}{lcccccc}
\hline \multicolumn{7}{c}{ Unstandardized Coefficients } \\
Model & B & $\begin{array}{c}\text { Standardized } \\
\text { Coefficients } \\
\text { Beta }\end{array}$ & t Error & & Sig. \\
\hline 1 & (Constant) & 16,262 & 1,611 & & 10,097 &, 000 \\
& Variablex1 &, 555 &, 253 &, 634 & 2,198 &, 003 \\
& Variablex2 &, 014 &, 342 &, 012 &, 040 &, 006 \\
\hline
\end{tabular}

a. Dependent Variable: Variabley 
Based on the table above, the counselling campaign variable dominantly influenced the healthy lifestyle of the community in Pura Aditya Jaya Rawamangun, Jakarta of 2.198. Meanwhile, the below-the-linecampaign did not really influence the healthy lifestyle of the community in Pura Aditya Jaya Rawamangun of 0.040 . The regression equation could be explained as below:

$$
\begin{gathered}
Y=a+b X \\
Y=16,262+0,555 X+0,014 X
\end{gathered}
$$

The constant of 16.262 implied that the constant value of Variable X1 and Variable X2 contribute 16.262 . The $X 1$ regression coefficient of 0.555 showed that every $1 \%$ addition in the value of the counselling campaign variable will cause an addition of 0.555 in the healthy lifestyle variable value. The $\mathrm{X} 2$ regression coefficient of 0.014 showed that every $1 \%$ addition in the value of below-the-line campaign variable will cause an addition of 0.014 in the healthy lifestyle variable value. The regression coefficients are positive, thus, the influence direction of the campaign through counseling (X1) and campaign through below-the-line (X2) on healthy lifestyle variables is positive.

\section{DISCUSSION}

Analysis results of this research show that the variable of Campaign through Counselling is dominant in influencing the clean and healthy lifestyle behaviour of people living in the area of Pura Aditya Jaya Rawamangun, Jakarta. This matter proves that communication in person is more effective than using the media. Therefore, the result is in line with researches that stated that direct communication (face to face) is way more effective, whether using digital technology or not (Dohen, Schwartz \& Bailly, 2010; Pea Nass, Meheula, ....., \& Zhou, 2012), and online interaction (Okdie, Guadagno, Bernieri, Geers \& McLarney-Vesotski, 2011; Andres, 2002; Baym, Zhang \& Lin, 2004).

The messages delivered in the campaign are regarding clean and healthy lifestyle behaviour in the COVID-19 pandemic era. According to the research, some respondents are still at high risk, since they still touch their face, did not use a face mask, did not practice physical distancing, consume less vegetable and fruit, and some still not fully stay at home. The result of this research is also in line with the research Gerakan Masyarakat untuk Hidup Sehat di Era Pandemi COVID-19, or Healthy Living Community Movement in Covid-19 Pandemic Era, (Zukmadani et al., 2020; Andriansyah \& Rahmantari, 2013; Kementerian Kesehatan Republik Indonesia, 2015; Malik et al., 2020; Proverawati \& Rahmawati, 2012; Sutton, 2020; Tin, Vivili, Na'ati, Bertrand \& Kubuabola, 2020; Wahyudin \& Uud, 2016; Yousfi, Bragazzi, Briki, Zmijewski \& Chamari, 2020).

The results of this study also proved that the people in Pura Aditya Jaya Rawamangun, Jakarta carry out the values of Tri Hita Karana. The community maintains and manages the environment responsibly by maintaining cleanliness and healthy living. The health communication campaign for Hindu community was successfully implemented and in accordance with the study on health communication during pandemic COVID-19 era (Wahyudin \& Uud, 2016; Yu, Li, Yu, He \& Zhou, 2020).

Based on the research results, it is proven that there is a positive influence of the PHBS (Clean and Healthy Behaviour) campaign through counselling and below-the-line media on clean and healthy lifestyle behaviour (Ayub et al., 2019) at Pura Aditya Jaya Rawamangun. In 
other words, Social Learning Theory (Jamilah, Gowri, \& Nur Nasliza, 2015; Bandura, 2001; Bandura, Caprara, Barbaranelli, Regalia \& Scabini, 2011; Othman, Talib, Hassan \& Kamarudin, 2014) is proven in this study. The community at Pura Aditya Jaya Rawamangun, Jakarta conducted social lessons on PHBS messages conveyed in the campaign. This social learning seems to be more effective during the Covid pandemic. Nobody wants to get infected by the Covid-19 virus which results in death. Therefore, the community is enthusiastic about learning to live a clean and healthy life more intensely to avoid transmission of the Covid-19 virus.

\section{CONCLUSION}

Based on the result of the research, it can be concluded that: there is a positive influence from the Clean and Healthy Lifestyle Behaviour (PHBS) campaign through counselling and below the line on the clean and healthy lifestyle behaviour of people in Pura Aditya Jaya Rawamangun. This phenomenon proves the Social Learning Theory in this research. The variable of Campaign through Counselling is more dominant in influencing the clean and healthy lifestyle behaviour of people in Pura Aditya Jaya Rawamangun Jakarta, compared to the variable of Campaign through media Below the Line.

It is highly suggested for the Pura or temple administrators to remain consistent in introducing the PHBS, and collaborating with the Ministry of Health in campaigning and providing counselling to Hindus to maintain clean and healthy lifestyle behaviour whether in the Pura area or the house environment.

\section{ACKNOWLEDGEMENT}

This research was funded by a Thesis research grant from the Indonesian Directorate of Higher Education. We would like to thank the ministry of education for providing this grant. We also express special gratitude to the Rector of Universitas Mercu Buana Jakarta who always gives his utmost support to us.

\section{BIODATA}

Wayan Tantre Miyane is a alumni of postgraduate communication science at Universitas Mercu Buana, Indonesia. Email: wayantantre96@gmail.com

Suraya Mansur is a Associate Professor in Communication Science. She is also a senior lecturer at Universitas Mercu Buana, Indonesia. Email: Suraya.suraya@mercubuana.ac.id 


\section{REFERENCES}

Amanah, S. (2007). Makna penyuluhan dan transformasi perilaku manusia. Jurnal Penyuluhan, 3(1). https://doi.org/10.25015/penyuluhan.v3i1.2152

Andres, H. P. (2002). A comparison of face-to-face and virtual software development teams. Team Performance Management: An International Journal, 8(1/2), 39-48. https://doi.org/10.1108/13527590210425077

Andriansyah, Y., \& Rahmantari, D. N. (2013). Penyuluhan dan praktik PHBS (Perilaku Hidup Bersih) dalam mewujudkan masyarakat desa peduli sehat. Inovasi dan Kewirausahaan, 2(1), 45-50.

Ayub, S. H., Hassim, N., Yahya, A. H., Hamzah, M., \& Bakar, M. Z. A. (2019). Exploring the characteristics of healthy lifestyle campaign on social media: A case study on FIT Malaysia. Jurnal Komunikasi: Malaysian Journal of Communication, 35(4). https://doi.org/10.17576/JKMJC-2019-3504-20

Bandura, A. (2001). Social cognitive theory of mass communication. Media Psychology, 3(3), 265-299. https://doi.org/10.1207/S1532785XMEP0303 03

Bandura, A., Caprara, G. V., Barbaranelli, C., Regalia, C., \& Scabini, E. (2011). Impact of family efficacy beliefs on quality of family functioning and satisfaction with family life. Applied Psychology, 60(3), 421-448. https://doi.org/10.1111/i.1464-0597.2010.00442.x

Baym, N. K., Zhang, Y. B., \& Lin, M. C. (2004). Social interactions across media: Interpersonal communication on the internet, telephone and face-to-face. New Media and Society, 6(3), 299-318. https://doi.org/10.1177/1461444804041438

Bungin, H. M. B. (2009). Sosiologi komunikasi: Teori, paradigma, dan diskursus teknologi komunikasi di masyarakat. Kencana Prenada Media Group.

Citrasiwi, G., Hafiar, H., \& Sjoraida, D. F. (2017). Pembentukan sikap masyarakat terhadap kesehatan diri melalui kampanye 10 perilaku hidup bersih dan sehat. Jurnal Visi Komunikasi, 14(2), 136-145.

Dohen, M., Schwartz, J. L., \& Bailly, G. (2010). Speech and face-to-face communication - An introduction. Speech Communication, 52(6), 477-480. https://doi.org/fgrzri

Emma Mohamad, Nur Afiqah Mohd Haniff, Sabariah Mohamed Salleh, Abdul Latiff Ahmad, \& Hasrul Hashim. (2015). Media dan literasi kesihatan: Pemilihan susu tumbesaran kanak- kanak dalam kalangan ibu. Jurnal Komunikasi: Malaysian Journal of Communication, 31(2).

Fajriani, H., Aliyudin, M., \& Ridwan, A. (2020). Respon mubaligh Banten terhadap materi dakwah Ustad Evie Effendi tentang Nabi sesat. Tabligh: Jurnal Komunikasi Dan Penyiaran Islam, 5(3). https://doi.org/10.15575/tabligh.v5i3.1936

Grier, S., \& Bryant, C. A. (2005). Social Marketing in Public Health. Annual Review of Public Health, 26, 319-339. https://doi.org/10.1146/annurev.publhealth.26.021304.144610

Handayani, R., Novaryatiin, S., \& Ardhany, S. D. (2016). Sosialisasi perilaku hidup bersih dan sehat pada anak-anak tingkat sekolah dasar di desa tabore kecamatan mentangai kalimantan tengah. Jurnal Surya Medika, 2(1). https://doi.org/10.33084/jsm.v2i1.363

Hardianto, A. W. (2019). Analisis stimulus-organism-response model pada "Dove Campaign for Real Beauty" 2004 - 2017. Transaksi: Jurnal BisnisEkosnomi dan Sosial, 11(1).

Hariko, R. (2017). Landasan filosofis keterampilan komunikasi konseling. Jurnal Kajian Bimbingan dan Konseling, 2, 41-49. https://doi.org/10.17977/um001v2i22017p041

Ishikawa, H., \& Kiuchi, T. (2010). Health literacy and health communication. BioPsychoSocial Medicine, 4(18). https://doi.org/10.1186/1751-0759-4-18 
Ismayani, N. (2019). Kesiapsiagaan terhadapi bencana gempa dan tsunami (Kampung Koto Nagari Sungai Pisang Kabupaten Pesisir Selatan). Jurnal Pengabdian Kepada Masyarakat Dewantara, 1(2), 41-47. http://ojs.unitas-pdg.ac.id/index.php/ipmd/402

Jamilah Ahmad, Gowri Sritharan, \& Nur Nasliza Arina Mohamad Nasir. (2015). The effectiveness of video and pamphlets in influencing youth on environmental education. Jurnal Komunikasi: Malaysian Journal of Communication, 31(1).

Karim, H. A. (2020). Health literacy among rural communities: Issues of accessibility to information and media literacy. Jurnal Komunikasi: Malaysian Journal of Communication, 36(1). https://doi.org/10.17576/JKMJC-2020-3601-14

Karsidi, R. (2001). Paradigma baru penyuluhan pembangunan dalam pemberdayaan masyarakat. Jurnal Mediator, 2(1).

Kementerian Kesehatan Republik Indonesia. (2015). 10 perilaku hidup bersih dan sehat di rumah tangga.

Klingemann, H.-D., \& Römmele, A. (2002a). Public Information campaigns \& opinion research: A handbook for the student \& practioner. SAGE Publication. https://doi.org/bc6gqg

Klingemann, H.-D., Römmele, A., Voltmer, K., \& Römmele, A. (2002b). Information and communication campaigns: Linking theory to practice. In authors (Eds.), Public Information campaigns \& opinion research: A handbook for the student \& practioner (Chap. 1). SAGE. https://doi.org/10.4135/9780857024534.d7

Manimaran Krishnan, \& Samsudin A. Rahim. (2015). Hubungkait komunikasi kesihatan dengan kesan hirarki isu kesihatan terhadap perubahan amalan gaya hidup sihat Jurnal Komunikasi: Malaysian Journal of Communication, 30(1). https://doi.org/10.17576/ikmjc-2014-3001-08

Malik, F., Bafadal, M., Wahyuni, \& Sahidin. (2020). Edukasi perilaku hidup bersih dan sehat (PHBS), gerakan menggunakan masker (GEMAS), serta penggunaan antiseptik dan desinfektan di Desa La Nipa Nipa, Kecamatan Katoi, Kolaka Utara, Provinsi Sulawesi Tenggara. Jurnal Pengabdian Masyarakat, 1(3).

McQuail, D. (2016). Mass communication. In G. Mazzoleni (Ed.), The international encyclopedia of political communication. Wiley. https://doi.org/f8z6

Mohamad, E., \& Azlan, A. A. (2020). COVID-19 and communication planning for health emergencies (correspondence item). Jurnal Komunikasi: Malaysian Journal of Communication, 36(1).

Mulyana, D. (2007). Ilmu komunikasi suatu pengantar (revisi). PT Remaja Rosdakarya.

Munawaroh, D., Suherdiana, D., \& Nase, N. (2020). Respon jamaah terhadap dakwah terhadap dakwah melalui TQN (Tarekat Qodiriyah Naqsabandiyah) (Penelitian di pondok pesantren Ibnu Ajhari Bekasi). Tabligh: Jurnal Komunikasi dan Penyiaran Islam, 5(1). https://doi.org/10.15575/tabligh.v5i1.1779

Namkoong, K., Nah, S., Record, R. A., \& Van Stee, S. K. (2017) Communication, reasoning, and planned behaviors: Unveiling the effect of interactive communication in an antismoking social media campaign. Health Communication, 32(1), 41-50. https://doi.org/10.1080/10410236.2015.1099501

Nicely Aken, S. (2008). Health communication: From theory to practice. JMLA: Journal of the Medical Library Association, 96(1), 72-73. https://doi.org/bkbmrc

Okdie, B. M., Guadagno, R. E., Bernieri, F. J., Geers, A. L., \& McLarney-Vesotski, A. R. (2011). Getting to know you: Face-to-face versus online interactions. Computers in Human Behavior, 27(1), 153-159. https://doi.org/10.1016/i.chb.2010.07.017 
Othman, A., Talib, O., Hassan, S. A., \& Kamarudin, N. (2014). Cognitive, afective and students' performance: A model of meaningful learning. Seminar Penyelidikan \& Pembangunan Sumber Manusia 2014.

Paramajaya, I. P. G. (2018). Implementasi konsep Tri Hita Karana dalam perspektif kehidupan global: Berpikir global berperilaku lokal. Purwadita: Jurnal Agama dan Budaya, 2(2).

Pea, R., Nass, C., Meheula, L., Rance, M., Kumar, A., Bamford, H., Nass, M., Simha, A., Stillerman, B., Yang, S., \& Zhou, M. (2012). Media use, face-to-face communication, media multitasking, and social well-being among 8 to 12 -year-old girls. Developmental Psychology, 48(2), 327-336. https://doi.org/10.1037/a0027030

Peng, Y., Pei, C., Zheng, Y., Wang, J., \& Zhang, K. (2020). Knowledge, attitude and practice associated with COVID-19 among university students: A cross-sectional survey in China. BMC Public Health 20(1292). https://doi.org/10.1186/s12889-020-09392-z

Proverawati, A., \& Rahmawati, E. (2012). Perilaku hidup bersih dan sehat (PHBS). Yogyakarta: Nuha Medika.

Rank, M. R. (2010). Below the line. In Author (Ed.), One nation, underprivileged: Why American poverty affects us all. Oxford University Press. https://doi.org/bpgp3q

Rice, R. E., \& Atkin, C. K. (2017). Public communication campaigns. SAGE Publication. https://doi.org/10.4135/9781544308449

Rimal, R. N., \& Lapinski, M. K. (2009). Why health communication is important in public health. Bulletin of the World Health Organization, 87(247). https://doi.org/d88gvx

Robandi, D. (2020). An analysis of education policy in the pandemic COVID-19. E-Tech: Jurnal IImiah Teknologi Pendidikan, 8(1). http://ejournal.unp.ac.id/index.php/etech/issue/view/1320

Sakinah, N., Sumijaty, S., \& Rahman, E. T. (2020). Respon komunitas pemuda Faiths Terhadap kajian Khitobah berbasis materi tauhid. Tabligh: Jurnal Komunikasi Dan Penyiaran Islam, 4(1). https://doi.org/10.15575/tabligh.v4i1.660

Sampurno, M. B. T., Kusumandyoko, T. C., \& Islam, M. A. (2020). Budaya media sosial, edukasi masyarakat, dan pandemi COVID-19. SALAM: Jurnal Sosial Dan Budaya Syar-I, 7(6). https://doi.org/10.15408/sjsbs.v7i5.15210

Saputra, R. (2016). Efek game online terhadap kreatifitas berpikir anak di Kelurahan Kadia Kecamatan Kadia Kota Kendari. Journal IImu Komunikasi UHO: Jurnal Penelitian Kajian IImu Komunikasi dan Informasi, 1(3).

Snyder, L. B. (2007). Health communication campaigns and their impact on behavior. Journal of Nutrition Education and Behavior, 39(2), S32-40. https://doi.org/ch63hm

Sugiyono. (2012). Metode penelitian pendidikan: Pendekatan kuantitatif, kualitatif dan R\&D. Bandung: Alfabeta.

Sutton, H. (2020). Keep your community safe while COVID-19 spreads globally. Recruiting \& Retaining Adult Learners, 22(8). https://doi.org/10.1002/nsr.30595

Thomas, R. K. (2006). Health communication. Springer.

Tin, S. T. W., Vivili, P., Na'ati, E., Bertrand, S., \& Kubuabola, I. (2020). Insights in public health: COVID-19 special column: The crisis of non-communicable diseases in the Pacific and the Coronavirus disease 2019 pandemic. Hawai'i Journal of Health \& Social Welfare, 79(5), 147-148.

Wahyudin, \& Uud. (2016). Membangun model kampanye komunikasi kesehatan PHBS di Jawa Barat. Jurnal IImu Politik dan Komunikasi, 6(2). 
Yousfi, N., Bragazzi, N. L., Briki, W., Zmijewski, P., \& Chamari, K. (2020). The COVID-19 pandemic: How to maintain a healthy immune system during the lockdown - A multidisciplinary approach with special focus on athletes. Biology of Sport, 37(3), 211216. https://doi.org/10.5114/biolsport.2020.95125

Yu, M., Li, Z., Yu, Z., He, J., \& Zhou, J. (2020). Communication related health crisis on social media: A case of COVID-19 outbreak. Current Issues in Tourism. https://doi.org/10.1080/13683500.2020.1752632

Zukmadani, A. Y., Karyadi, B., \& Kasrina. (2020). Edukasi perilaku hidup bersih dan sehat (PHBS) dalam pencegahan COVID-19 kepada anak-anak di panti asuhan. JPMPI: Jurnal Pengabdian Masyarakat Pendidikan IPA, 3(1). 